\title{
Romantic Relationships and Criminal Desistance: Pathways and Processes ${ }^{1}$
}

\author{
Jessica J. B. Wyse, ${ }^{2}$ David J. Harding, ${ }^{3}$ and Jeffrey D. Morenoff ${ }^{4}$
}

\begin{abstract}
In dominant theories of criminal desistance, marital relationship formation is understood to be a key "turning point" away from deviant behavior. Empirical studies supporting this claim have largely focused on the positive role of marriage in men's desistance from crime, and relatively few studies have examined the role that nonmarital relationships may play in desistance. Drawing on 138 longitudinal in-depth interviews with 22 men and women reentering society from prison, this article extends the scope of desistance research by additionally considering the significance of more fleeting and fluid relationships, and the diverse processes through which romantic relationships of all sorts are linked with criminal behaviors. We present an empirically based typology detailing six processes, grouped within three conceptual categories, through which romantic relationships had their effects. These pathways include material circumstances, social bonds and interactions, and emotional supports and stressors. We also consider gender differences in these processes. While more tenuous bonds to marginally conventional partners would seem to exert little effect, as one of the few relationships and social roles available to many former prisoners, we found that they wielded important influence, if not always in a positive direction.
\end{abstract}

KEY WORDS: criminal desistance; emotional support; prisoner reentry; romantic relationships; social bonds; social control.

\section{INTRODUCTION}

The formation of high-quality marital relationships is understood to be one of the key potential "turning points" in desisting from crime (Bersani, Laub, and Nieuwbeerta 2009; King, Massoglia, and MacMillan 2007; Laub and Sampson 1993, 2003; Sampson, Laub, and Wimer 2006; Warr 1998). Marriage, however, has become increasingly rare among criminal offenders and returning prisoners (Giordano, Cernkovich, and Rudolph 2002; Western 2007), and studies that have considered a broader range of romantic relationships have not yielded consistent findings. For example, an increasing number of studies have shown that some

1 This research was supported by grants from the Office of the Vice President for Research, Rackham Graduate School, Department of Sociology, Joint PhD Program in Sociology and Public Policy, National Poverty Center, and the Population Studies Center of the University of Michigan, which is supported by the National Institute of Child Health and Human Development under Grant R24 HD041028. Additional support was provided by an NIA training grant to the Population Studies Center of the University of Michigan (T32 AG000221). We thank Elizabeth Johnston, Andrea Garber, Elena Kaltsas, Madie Lupei, and Carmen Gutierrez for excellent research assistance.

2 Institute for Social Research, University of Michigan, 426 Thompson St., Ann Arbor, Michigan 48106; e-mail: jwyse@umich.edu.

3 Department of Sociology, University of California at Berkeley, 410 Barrows Hall, Berkeley, California 94720 .

4 Institute for Social Research, University of Michigan, 426 Thompson St., Ann Arbor, Michigan, 48106. 
romantic relationships actually encourage criminality, particularly when partners are themselves engaged in antisocial behaviors (Capaldi, Kim, and Owen 2008; Haynie et al. 2005; Simons et al. 2002). This article extends the scope of current criminal desistance research by considering the significance of a broad array of romantic relationships, and a more diverse array of social processes through which relationships may be linked with desistance. We build on recent ethnographic work on the importance of intense but fleeting "disposable ties" in the survival strategies of the urban poor (Desmond 2012) and argue that given the dearth of resources, attachments, and identities to which many former prisoners have access, romantic relationships of even the most tenuous sort may prove deeply influential to desistance processes. ${ }^{5}$

Drawing on empirical examples from qualitative research on returning prisoners, we offer a conceptual framework that identifies and explicates the primary pathways through which romantic partnerships can enhance or hinder efforts to desist from crime after prison. This framework incorporates theoretical insights from prior research on the protective effects of marriage but also considers pathways through which romantic relationships can encourage criminality, particularly when offenders' partners are engaged in anti-social behaviors. Incorporating insights from research on women's desistance-such as the potential for romantic relationships with criminally involved men to become pathways into crime for women-we also consider gender differences in the role of romantic relationships in desistance (Chesney-Lind and Shelden 1998; Daly 1994; Giordano et al. 2002; Harm and Phillips 2001; O'Brien 2001; Steffensmeier and Allan 1996).

Our research is based on 138 longitudinal qualitative interviews with 15 male and 7 female prisoners in Michigan during their final months in prison and the 2 years following release. We draw upon our participants' accounts of past and current relationships, as well as their attitudes toward relationships as they leave prison and, in most cases, attempt to create crime-free lives for themselves. To organize our findings we present an empirically based typology detailing six processes through which romantic relationships may be linked with criminal desistance. We group these processes into the categories of material circumstances, social bonds and interactions, and emotional supports and stressors. Although many of the pathways function similarly for men and women, we also identify gender differences, which stem both from traditional gender roles within relationships as well as the reality of men's greater involvement in substance abuse and criminality.

\section{ROMANTIC RELATIONSHIPS AND DESISTANCE}

In recent years, a growing body of work has addressed the connection between romantic partnership and criminal desistance, much of it sparked by Sampson and Laub's (1993) analysis of a cohort of men who were first selected for study by the Gluecks (1950) in 1940, when they were adolescents living in Boston. The long-term

\footnotetext{
${ }^{5}$ We do not mean to suggest that tenuous or fractious bonds are the only type of romantic relationships formed by former prisoners; indeed, quite a few subjects were involved in committed pairings. Rather, we highlight these relationships as those neglected by past research, focused as it is on strong bonds to conventional partners.
} 
follow-up of this sample has produced an impressive body of evidence supporting the claim that men who enter into marriages characterized by high levels of attachment are more likely to cease or reduce their participation in criminal activity (Laub and Sampson 2003; Sampson and Laub 1993; Sampson et al. 2006). Protective effects of marriage have been found in other studies of criminal offending as well (Barnes and Beaver 2012; Bersani et al. 2009; Horney, Osgood, and Marshall 1995; King et al. 2007; Warr 1998).

Marriage is understood to promote informal social control (and thus desistance) through four primary pathways (Sampson et al. 2006). First, marriage increases the potential cost of crime because criminal activity may threaten the bond of attachment and lead to its dissolution (Hirschi 1969; Sampson and Laub 1993). Second, marriage may keep ex-offenders away from situations and social relationships that present criminal opportunities and influence (Cohen and Felson 1979; Osgood et al. 1996; Warr 1998). Such changes can have a particularly strong dampening effect on crime for men, who otherwise would be more likely to either associate with criminal peers or put themselves in places and situations that present greater criminal opportunities. Third, marriage provides structure and supervision, particularly when the partner expects the offender to have a legitimate job, contribute income, and support the household, and to avoid activities that might threaten the family's economic stability. Fourth, marriage can provide both partners with identities that are inconsistent with criminal behavior. Marriage may change the way people see themselves, their responsibilities, and their relationships with others, strengthening the ability of conventional norms to govern behavior, lest criminal activity conflict with role expectations, such as that of the provider.

While research findings have coalesced around the idea that high-attachment and/or marital relationships encourage men's desistance via processes of informal social control, the role of romantic relationships in women's desistance is less clear. While some research finds that marriage or strong, high-quality relationships suppress women's participation in crime and substance use, others find that romantic relationships have offsetting or null effects on women's antisocial behavior, and still others suggest that romantic relationships increase women's participation in some forms of criminal activity depending on the timing and context (Alarid, Burton, and Cullen 2000; Bersani et al. 2009; Cobbina, Huebner, and Berg 2010; Giordano et al. 2002; Griffin and Armstrong 2003; King et al. 2007; Leverentz 2006; Sterk 1999; Thompson and Petrovic 2009). This ambiguity, likely reflecting men's higher level of criminal engagement and thus heterosexual women's lower likelihood of forming a relationship with a conventional partner, suggests that the social control tradition may not be the most useful model for understanding the influence of relationships in women's desistance, and that additional theoretical development is needed.

\section{Contemporary Relationships and Mechanisms of Desistance}

Although research interest in marriage and crime is stronger than ever, the prevalence of marriage itself continues to decline, especially among people who 
have committed criminal offenses or been incarcerated. For example, the rate of marriage among incarcerated men is only half that of nonincarcerated men (Western 2007), and nearly half of incarcerated women have never married (Greenfeld and Snell 1999). In stark contrast, more than three-quarters of the men in the sample selected by the Gluecks in 1948 were married by age 31 (Glueck and Glueck 1968). Cohabitation has also become more common as a predecessor to or substitute for marriage, especially among people with lower incomes and levels of education (Bumpass and Lu 2000; Edin and Kefalas 2005; Smock 2000; Smock, Manning, and Porter 2005). Studies of ex-offenders have found high rates of involvement in cohabitation or other nonmarital romantic relationships (Giordano et al. 2002; Leverentz 2006; Western 2007).

Moving even further away from a focus on relationships characterized by a strong bond to a conventional partner, recent research on the social ties formed by the urban poor suggests that, for those with few resources, even fleeting, conflictridden relationships may have important emotional and material significance (Gerstel 2011). Desmond (2012:1311) defines these "disposable ties" as "relations between new acquaintances characterized by accelerated and simulated intimacy, a high amount of physical copresence (time spent together), reciprocal or semireciprocal resource exchange, and (usually) a relatively short life span." Such shortterm, expedited emotional and material reliance may well characterize the romantic partnerships formed by economically marginalized, socially isolated ex-offenders, and thus have important implications for criminal desistance.

Yet relatively few studies have examined the association between nonmarital relationships and desistance, and the findings from this research are inconsistent. Although some studies have linked cohabitation to reductions in crime and substance use, others have found either that cohabitation has no significant effect on crime or that it increases criminal offending (Duncan, Wilkerson, and England 2006; Horney et al. 1995; Sampson et al. 2006; Warr 1998). Thus, it is unclear whether nonmarital relationships possess the same crime-suppressing qualities as marriage, and discrepant findings from prior studies call into question whether theoretical accounts focused on mechanisms of social control are sufficient for understanding the complex role that other types of romantic relationships may play in desistance.

Recognizing the potential significance of relationships not easily characterized along a spectrum of weak to strong, or marital to "hooking up," our analysis focuses not on the implications of relationship type, but rather the mechanisms through which relationships have their effects. The mechanisms we identify occur at the interactional level, in the interplay between individual needs, identities, and relationship roles.

In the results that follow we draw upon longitudinal qualitative interviews with a small sample of returning prisoners to provide thick descriptions of the processes and pathways through which relationships may influence desistance.

\section{DATA AND METHODS}

We take an inductive approach, relying upon qualitative methods as those best suited to uncovering diverse and complex social processes. In unstructured 
interviews the researcher can begin to reveal the participant's understanding of his or her experiences, gather data on the details of those experiences, and explore if and how the processes suggested in the literature square with the participant's experiences and conceptualizations (Lofland and Lofland 1995). Our data come from in-depth longitudinal interviews that probe the social, economic, and cultural processes related to prisoner reentry and criminal desistance. Findings draw upon 138 interviews with 22 participants. We intentionally chose to study a small number of subjects intensively over a relatively long period of time because such a design provides the best means of capturing rapid changes that occur over the reentry period, as well as outcomes that take time to develop. Because statistical representativeness is impossible in a study with a small sample size, we instead pursued a "purposive" sampling strategy common to qualitative research (Kuzel 1992). Accordingly, the sample was stratified by gender, race (white vs. black), reentry county (urban vs. suburban), and type of release. Within these categories, potential subjects available at the time of recruitment were selected at random. This sampling strategy ensures that theoretically important categories are present and therefore that conclusions drawn are not particular to the largest group of former prisoners in the population (minority males released to central cities). As such we do not aim to represent the modal experience of returning prisoners with these data.

The final sample consisted of 15 male and 7 female participants; was half white and half black (Latinos make up a very small percentage of Michigan prisoners). Participants ranged in age from 22 to 71, with most participants in their late-twenties to early-forties. The participants had been convicted of a wide range of crimes, from retail fraud to manslaughter. Eight participants were being released from prison for the first time; all others had experienced multiple prison spells. Although a small sample with a high degree of variation, such as ours, would be ill-suited to a quantitative analysis of associations between variables, such a diverse sample is ideally suited to an inductive, qualitative study that seeks to identify and describe processes and mechanisms. Specifically, our sample allows us to capture a wide range of relationship experiences and perspectives.

In total, we were able to maintain regular contact with 14 participants across the 2-year period but had fewer interviews with four participants who were reincarcerated and one who was killed during the observation period. Three additional participants were lost to follow-up, one after 2 months of observations, another after 12 months, and a third after 20 months. Additional details of methodology, including interview timing, can be found in the online appendix.

Interviews covered a diverse array of topics, both researcher and participant driven, but focused on the participant's community context, family roles and relationships, criminal activities and experiences, and health and well-being. Initial inprison interviews were roughly 90 minutes long, while follow-up interviews spanned 1-2 hours on average. Research participants were matched with interviewer on gender but not on race. Over the period of the study trust and rapport deepened, and many participants became more forthcoming regarding sensitive information. All interviews were recorded and transcribed. The coding and analysis of the field notes and transcripts was conducted using ATLAS.ti qualitative software. An initial list 
of codes was generated prior to analysis based on theoretically motivated categories and concepts, and additional descriptive codes were generated during the course of the analysis.

Our longitudinal data allowed us to capture the complexity of participants' relationship experiences over time. Though a few participants remained within a single marital relationship across the study period, for most, breakup and reunion, or the formation of a new relationship, was common. Of the 15 male participants, two were married, one separated, one divorced and not currently in a relationship, and one engaged at the time of the most recent interview. In addition, eight men were cohabiting at some point during the study and five were dating. Only one man was in a single committed relationship across the entire period, though four men formed new relationships that endured through the course of the study. Of the seven female participants, one was married, three cohabiting, and three were in noncohabiting romantic relationships (in one of these the partner was incarcerated). Only one woman was in a single committed relationship across the entire period, though two women formed new, enduring relationships.

The idea for this article emerged inductively from the data as we began to recognize the complex role relationships played in the lives of our participants. We developed our analysis by first identifying each romantic relationship discussed by our participants, whether historical or contemporary, and tracing his or her experiences in the relationship and understandings of these relationships over time. Specifically, we sought to understand how participants thought about the role relationships played in their own decision to desist from, or return to, crime, as well as the particular processes through which this occurred. We also considered how relationships affected criminal offending indirectly, through processes linked with criminal behaviors, particularly substance use. For the purposes of this analysis, we considered desistance to be the avoidance of illegal behavior, whether or not such behavior was known to law enforcement authorities. By this definition, 4 of 15 men and 2 of 7 women continued to desist from crime 2 years after release.

Based on our analysis, we constructed a typology of the primary pathways through which participants' relationships were linked with criminal desistance or return to crime. We found that relationships often influenced participants through more than one pathway; in many cases the data revealed that the same factor and even the same relationship had both positive and negative effects on desistance. In the results that follow we intentionally highlight the experiences of just a few of our research participants - both within and across relationships - to better capture this complexity.

The reader should note that this article focuses on participants' own descriptions and perceptions of the ways in which romantic partnerships are linked with their criminal behaviors. We do not claim that we are able to present strong evidence that the processes we identify are causally connected to desistance outcomes. While the relatively small qualitative sample upon which our data is drawn provides rich fodder for identification and description of mechanisms, it is limited in its ability to make causal claims. 


\section{RESULTS}

To structure the results from our interviews, we present a typology identifying six interconnected pathways through which romantic relationships influenced our participants' desistance (see Table I). The mechanisms we identify are grouped into the following categories: material circumstances, processes related to social bonds and interactions, and emotional supports and stressors. Within each broad category, we identify mechanisms both protective of, and potentially detrimental to, desistance goals. We also identify gender differences we observed in how subjects experience romantic relationships and argue that these gender differences appear linked to traditional gender roles, such as that of breadwinner, as well as to men's greater involvement in criminal and antisocial behaviors.

\section{Relationships and Material Resources}

Positive-Instrumental Support Instrumental support, which has been defined as "the use of the relationship as a means to a goal" (Lin 1986), has received surprisingly little mention in criminological research on romantic relationships and crime. ${ }^{6}$ Relationships can be a source of instrumental support by providing material aid (such as money or housing), or advice and guidance toward achieving specific goals. Such support can be crucial for former prisoners, who enter the community often with little more than the clothes on their backs, yet require housing as well as transportation, food, and spending money almost immediately.

DeAngelo is a 27-year-old African American who was concluding his second stint in prison when we began our study. His first prison sentence was a 3-year term at age 21 for breaking and entering an unoccupied building; he explained that he and his brother, who had been homeless, were seeking a place to sleep. At 26, a third drunken driving conviction landed him in prison again. During this prison bit, DeAngelo was diagnosed with severe depression, bipolar disorder, and acute

Table I. Theoretical mechanisms through which romantic relationships may affect desistance.

\begin{tabular}{lcl}
\hline $\begin{array}{l}\text { Mechanisms Through Which Romantic } \\
\text { Relationships May Influence Desistance }\end{array}$ & $\begin{array}{c}\text { Direction of } \\
\text { Influence on } \\
\text { Desistance }\end{array}$ & Theoretical Traditions \\
\hline $\begin{array}{l}\text { Material Circumstances } \\
\text { Instrumental support }\end{array}$ & + & $\begin{array}{l}\text { Control Theory, Strain Theory } \\
\text { Role strain }\end{array}$ \\
$\begin{array}{l}\text { Social Bonds and Interaction } \\
\text { Monitoring/supervision by partner }\end{array}$ & - & $\begin{array}{l}\text { Control Theory } \\
\text { Coercion/negative social control }\end{array}$ \\
$\begin{array}{l}\text { Emotional Supports and Stressors } \\
\text { Expressive support }\end{array}$ & - & $\begin{array}{c}\text { Support and Coercion } \\
\text { Supherential Social }\end{array}$ \\
Relationship stress & + & $\begin{array}{c}\text { Control Theory, Strain Theory, Social } \\
\text { Support Theory } \\
\text { Control Theory, Strain }\end{array}$ \\
\hline
\end{tabular}

${ }^{6}$ See Siennick (2011) for a discussion of parents' financial support for their criminally involved adult children. 
anxiety, and realized that these conditions had been accentuated by his alcoholism. When he was paroled, DeAngelo's 19-year-old girlfriend picked him up from prison, and he moved in with her and her mother.

In an interview 2 months following his release, DeAngelo explained that although his living situation was stressful, it was far superior to the alternative, a homeless shelter:

Well, I ain't got nowhere to go.... I'm not about to go to no homeless shelter [laughs]. That would just mess me up emotionally. Like, I'm living in a homeless shelter? Even though it's sort of like that same thing here because it's not my house. But it's not as bad as the homeless shelter. People will see me going in and out of there.... And they all just raggedy, broke. It would depress me. I ain't going there. But I know I really don't have no other option.

Although residing with his girlfriend and her mother was far from a perfect living situation, DeAngelo remained there in the months following his release because he had no other options, and worried that going to a homeless shelter would trigger a bout of depression and return to drinking. Living with his girlfriend, DeAngelo felt secure that he had a roof over his head and food to eat, at least for the time being. Six months after he was released, he revealed that negative characteristics of his girlfriend and the relationship were beginning to outweigh the benefits, which eventually led him to leave the house and the relationship, at least for a time. Though this relationship was severed relatively quickly, it nonetheless had important material consequences for him; because he had been able to save money during his stay, he was able to move into his own apartment with the help of a state program for returning prisoners.

The importance of even a minimal level of material support is clear when we contrast DeAngelo's experience with that of the single Randall, a 33-year-old African American who, like DeAngelo, grew up in a troubled home in Detroit and was on parole for the second time. Randall had nine felonies, including firearm possession, car theft, and drug dealing. Due to his criminal past, he was estranged from most of his family and had no romantic partner to call on for help. Randall paroled to a drug program in Detroit and then bounced around for over 6 months between homeless shelters, programs, and couches before finding a more permanent home with his half-sister. With a long felony record, no high school diploma, no telephone, and often no money for bus fare, Randall was never able to find a job. Although he was determined to straighten out before he left prison, after weeks without any money except what he could beg from family and friends, he went back to selling marijuana:

I'm going to be on the real. I know it was wrong, but I've been selling weed. Trying to keep some money in my pocket. But I ain't out here just selling to anybody, I'm out here trying to keep some money in my pocket until I find a job. I don't like walk around with no pound [of marijuana], or nothing like that on me.... I sort of try to maintain.

Randall's drug dealing was never discovered by his parole officer or the police, and he stopped after he finally found a permanent home with his stepsister.

Like DeAngelo, many of our participants relied on romantic partners for material support, even when they worried that the relationship was otherwise unsupportive of their desistance goals. Consider Jennifer, a white 38-year-old who had been a 
severe heroin and crack addict since adolescence. Throughout her adult life her main sources of financial support had been drug selling and her male partners. Upon leaving prison, she planned to move in with her longtime, elderly fiancé, with whom she had used drugs in the past. Although she recognized that he was not a positive influence on her desistance goals, she stayed with him because he offered substantial material support: housing, food, transportation, and income from disability benefits.

A few months following her release, the opportunity arose for Jennifer to inherit a trailer home from an ailing, older aunt. Presented with an alternative, she chose to move, explaining that she could not continue to live with her fiancé because of their shared history of drug use. However, with no income, no credit, and a felony conviction, she could not sign the trailer park lease or afford the rent alone. For help she turned to her son's father, John, a "good man" with a steady income from disability payments with whom she had been involved in the past. While the relationship was short-lived, as conflict over his reliance on prescription painkillers escalated into an incident of domestic violence, it allowed her to secure the lot and pay rent until she was able to establish her own public benefits. Like Jennifer, all of our female participants faced substantial material need, and in several cases had even spottier work histories than the men, having previously relied on prostitution, drug selling, and retail fraud to make ends meet.

Negative-Role Strain. Above, we emphasized how material support provided in relationships may support efforts to desist from crime. However, reliance on a partner for material support may also have negative consequences, especially among male returning prisoners, because these situations may lead to role strain. Failure at the provider role through conventional means may lead to criminal activity as an alternative way to fulfill these responsibilities. Though clearly consistent with strain theory (Agnew 1992; Ganem and Agnew 2007), we are not aware of any prior research examining the effect of role strain within a partnership on crime.

Consider David, a white 28-year-old with a history of breaking and entering to support his drug habit. A few days after he was paroled, he left his drug treatment program early and failed to contact his parole officer-an act of "absconding." Unable to stay with his mother or other family members for fear that authorities would find him, David was taken in by his former girlfriend Loretta, the mother of his child, and they soon resumed a relationship. They lived in a low-income housing complex with their daughter and Loretta's two other children. To get by, they relied entirely on Loretta's public benefits, including rent vouchers and food stamps. Over time David became increasingly stressed about not bringing any income into the household. At his first post-release interview, 4 weeks after release, he explained that he even considered limiting his own eating because he was not contributing income: "I wasn't eating for a minute.... I felt like I was taking out of the children's mouth; that's not my food." Still, David continued living with his girlfriend, who bought him not only food but also cigarettes and beer.

After he was returned to prison David noted that the strain of living off his girlfriend's largesse was one of the main factors that led him to resume criminal activity. He had noticed that one of his girlfriend's neighbors often left her apartment 
for weeks at a time. Just weeks after our interview, David seized the opportunity and burglarized the neighbor's apartment after a night of drinking. He explained that the main reason he committed the crime was that he could not continue living in the household without contributing financially. He had planned to pawn the stolen goods to help with household expenses, but police arrived the next morning.

It would seem that, for David, being in a relationship initiated a particular role expectation that served more as a motivation for criminal involvement than a protective factor. We observed other men in our sample like David, who described their inability to fulfill the provider role as motivation for income-generating criminal actions. Moreover, several men who were later arrested for criminal offenses, such as car theft, had in previous interviews expressed considerable discomfort with being unable to contribute.

Such role strain can be understood to be closely linked to traditional gender norms that dictate that a man's role in a romantic relationship is to provide material resources. Some of the single men in our sample even cited their inability to fulfill the role of breadwinner as a reason for avoiding romantic relationships. Lamar, a single African American man in his forties who had served two prison terms for armed robbery in the past, explains why he has no interest in a serious relationship, not just with his current girlfriend, but with any woman:

Have you ever been in a relationship and been the broke party? It doesn't make a good relationship where it's difficult for one to reciprocate. So let's say if I'm unemployed, I'm broke and you have someone who has finances, and it's like they're giving, and I'll just say for me, I don't feel comfortable not being able to reciprocate.

While Lamar describes this concern as emanating out of his own role expectations, he added that some partners could also pressure men to fulfill the provider role, reinforcing the stress of relationship involvement. Despite this, many participants were often left with no choice. Because of their weaker connections to family, they were often dependent upon romantic partners.

While some men were able to adapt to this strain by contributing in other ways, such as cleaning, cooking, house repair, and child care, most understood these in-kind contributions as solutions only in the short term. In the long term, most men believed they could not remain in relationships in which they were unable to contribute monetarily, even if they were able to contribute in these other ways. While our female participants also contributed extensively to housework and child care, they did not seem to view this as an exchange for the material support they received; rather, such labor was described as a normal and expected aspect of their daily routine.

More generally, our female participants did not seem to face the internal conflict over relying upon partners for material support. Consider white, 25-year-old Michelle, a minister's daughter with a history of serious drug abuse and homelessness. In a period of sobriety, she had met her fiancé, Luke, at an Alcoholics Anonymous meeting. Although the couple broke up and reunited several times over the years that followed, they were together when Michelle entered prison. The relationship was stormy during her incarceration. Michelle barred him from visiting her in prison and refused to talk to him on the phone at times. She was frustrated that he 
had been able to stay clean while she had not. Nonetheless, before her release, Michelle discussed numerous ways she planned to rely on him for material support.

When she was released, Michelle had little money, no driver's license or car, and no job. In the 6 months following her release Luke helped substantially by driving her to appointments, covering her expenses and providing her with spending money. He was also an integral part of her long-term plan to reestablish custody of her daughter.

\footnotetext{
I see this [as] just about a year because of me and my boyfriend working together. It probably would take me longer if I was doing it on my own, but I'm also not depending on him to do it with me because you never know what's going to happen, and I have to make sure that I can take care of [my daughter] by myself. But I have a lot of support.... There's a lot of family support as well as my boyfriend and his family....
}

Michelle's concerns about relying on her boyfriend differ from those of our male participants, as she expressed no concerns about being supported by him. Rather, her concern was about the relationship dissolving and how she might survive on her own if it did. Such a perception of relationship insecurity aligns with past research on poor women's beliefs about, and experiences with, romantic relationships (Edin and Kefalas 2005).

Although our female participants did not describe experiencing role strain, material support often came at a price. Exposure to drugs and alcohol via their partner's use or selling was not uncommon, and having a male partner sign the lease could have serious consequences if the relationship were to go badly, or if she were to experience domestic violence. When women did express fear of material dependence, it was not damage to their gendered self-concept that they feared, but rather a loss of control over their lives.

\section{Relationships and Social Interactions}

Positive-Monitoring and Supervision. A pillar of Sampson and Laub's (1993) agegraded theory of informal social control is that partners monitor and supervise one another to enforce their mutual obligations and restraints.

For DeAngelo, described above, not only did his relationship provide him with much-needed material resources upon his release from prison, but his girlfriend also provided an important supervisory role, imposing restrictions on his activities and social interactions. Although he initially chafed at the controls his girlfriend imposed upon him, 16 months after his prison release, he saw her actions differently: he recognized that these restrictions had improved his chances of desistance.

R: $\quad$ I used to think that she was being controlling, but she was really looking out for me, and I guess my pride and my ego was getting in the way, that's why we clashed a lot.

I: $\quad$ What was she trying to get you to do?

R: I would be like, "I'm going to Detroit with such and such." She'd be like, "No, I don't want you going with him. You know that dude always carries guns with him," or "You're going to Detroit looking like that? Somebody might try and rob you or something." "Man ain't nobody going to rob me, and he ain't got no gun. He ain’t going to put me in that situation." But really she was just thinking 
about the what-if factor, and I shouldn't be taking that risk. She just wanted to see me do right, man. I need to do right and I'm not going to say I'm weak and I can't do it on my own, but it's always good to have somebody that's there with you to kind of help keep you on your toes.

While initially DeAngelo's view of his girlfriend's supervisory behavior contributed to conflicts that hastened the relationship's demise, after the two got back together, he reframed this behavior as supportive of his desistance goals. In tenuous relationships, processes of supervision and monitoring may simultaneously protect against problematic behaviors while spurring conflicts that threaten the very foundation of the partnership.

Monitoring and supervision were similarly present in our female offenders' relationships. This was the case for white, 48-year-old Jane, who has a lengthy history of both drug addiction and criminal behavior. Her most recent period of imprisonment was her fourth. Before going to prison, Jane held a series of unconventional and criminal jobs, from topless dancing and running an escort service to drug selling and prostitution. Prior to her release, Jane predicted that her life was going to be different when she got out this time because she had "someone to go back to." At our first post-prison interview Jane explained that her relationship with her husband kept her clean and sober, "It's very good [the marriage] because I'm doing the right things, and it makes him happy. And when he's happy, I'm happy." Jane's husband strongly encouraged her abstention from substance abuse and her investment in the relationship encouraged her to stay away from drugs. However, Jane's husband also maintained a small side-business selling crack, heroin, and other hard drugs to supplement their income. When his hours at a Detroit factory were scaled back, he began to spend more time away from home selling drugs. Seven months after her release, in our fourth interview, Jane explained that she had relapsed just days previously, using the drugs that her husband kept easily accessible in a bedroom closet. Following this relapse, Jane's husband stopped allowing her to use the family car, gave her less spending money, and threatened to cut off her cell phone. He also monitored her daily activities by calling to check on her multiple times each day.

Jane's case illustrates the complexity of the connection between relationships and desistance. On the one hand, Jane's husband monitored and supervised her behavior (though in an increasingly controlling manner). On the other hand, his criminal involvement made Jane's desistance goals more difficult to achieve by increasing her access to drugs. Nearly 2 years after her prison release Jane continued to cycle through periods of relapse and recovery, both of which were supported by her relationship, albeit along different pathways.

While women in our sample did experience supervision and monitoring within their relationships, their partners' criminal involvement and/or addictions often meant that they were weakly positioned to exert conventionalizing control. Because most women's offending was tightly linked to their drug and alcohol abuse, a drugor alcohol-involved partner was unlikely to play a purely supervisory role, as Jane's case illustrates.

The conventionality of the partner similarly influenced men's criminal behaviors, as Lamar eloquently describes. 
I've been in relationships where the females I was with, they were doing good things and trying to get places in life and so me being in a relationship with them, I'd say that that was rubbing off on me. Being a thug and a street guy was not something that they wanted within their life, so that was something that I kind of would put on the back burner, and I was striving in that light in which they were shining.

In contrast, Lamar also described former partners who did not care about his involvement in crime:

But then there was times when I was in relationships with people who liked ripping and running the streets and was very street oriented, so they didn't care about me doing crime, so that made it a lot easier because it wasn't like I had to hide anything. Then I can just come home and she'll know already that I ain't got no job, so she'll be like, "Well, where you get all this money from?" And I can just be like, "Well, I went and robbed."

Supervision and monitoring by "street-oriented" partners would not curb Lamar's criminal behaviors, because these partners accepted and even shared such behaviors. In contrast, crime threatened his relationships with conventional partners, whose normative lifestyle also served as a model for his own.

Negative-Coercion and Negative Social Control. Although the restrictions and restraints that romantic partners impose can often benefit returning prisoners in their efforts to desist, in other circumstances, romantic partners channel such influence to encourage or coerce one another into remaining active in crime, substance use, or other forms of antisocial behavior (Colvin, Cullen, and Vander Ven 2002). Coercion can thus be viewed as the negative counterpart to the protective effects of partner-based social control.

Jada, African-American and aged 31, lives in a working-class Detroit suburb. Prior to her incarceration she held a steady job as a home-health aide for 11 years while caring for her two daughters. At our initial in-prison interview she was completing a 2-year prison term for smuggling drugs into a men's prison. Jada explained that when she was finally caught, she had been smuggling drugs into the prison for months at her boyfriend's request. At the time of this crime, she had been on probation for drug dealing and firearm possession, the same offenses for which her boyfriend had been incarcerated. Jada's boyfriend, the father of her younger daughter, was a partner in each of her crimes. This relationship directly contributed to Jada's criminal involvement, as many of her crimes were facilitated by her boyfriend and often benefited him.

Romantic partners also provided our participants with opportunities for drug relapse, which served as pathways to crime. In the lingo of Alcoholics Anonymous, exposure to "old places and old faces" is an easy route to relapse, which can then renew the cycle of criminal offending. Forty-four-year-old, white Kristine was able to establish sobriety in prison, but a past boyfriend and former partner in heroin use remained on the streets. Although she had avoided seeing or talking to him initially following her prison release, after 3 months on parole she changed her mind:

He called me and asked me how I was doing. I told him everything and I said, "Well, I want to come and see you." And he's like, "Well," he said, "are you sure?" I said, "Yeah, yeah, you know, I'm okay." And we ended up going out there and, you know, looking for Pete, finding Pete and then I ended up getting high being around everyone. 
While it may have been that deciding to meet him indicated a desire to use again, seeing him also facilitated her relapse. Following this relapse, Kristine absconded from parole and began supporting herself and her drug habit by shoplifting and selling stolen goods. Soon thereafter she was arrested for retail fraud and sentenced to a year in jail. The facilitation of recidivism by romantic partners was particularly common among female participants who partnered with criminal or drug-using men. It is important to note that we did not see this pathway among our male participants. We believe this is because men's female partners were simply not as criminally involved as were women's male partners.

\section{Relationships and Emotional Dynamics}

Positive-Expressive Support. Whereas much of the theoretical and empirical focus of the literature on relationships and desistance has been on the ways in which romantic partnership affects patterns of social interaction and routine activities, less appreciated is their role in providing emotional support that can buffer individuals from the effects of stressful life events that may lead to violence, substance use, or rash decision making (Cohen 2004; Cullen 2004; Umberson, Crosnoe, and Reczek 2010). Such support can be particularly important given the emotional challenges posed by imprisonment: men felt they had to present a tough, emotionally distant demeanor in order to stay safe, while women felt isolated and lonely. Upon release, former prisoners face a period of emotional upheaval, as their high expectations, for themselves as well as for others, meet often harsh realities. We observed many instances in which romantic partners provided a sympathetic ear to talk through problems or stressful events, affirmation, and confidence boosts in an otherwise lonely time, though this was substantially more common among men than women. These relationships often replaced more harmful alternatives for dealing with stress and emotional problems, such as substance use.

Consider 27-year-old, white Jake, who was released from his second term in prison after serving 3 years for drunken driving. Once Jake was paroled, he began a romantic relationship with Anna, a friend of his sister with whom he had corresponded in prison. Soon thereafter, Jake came to rely on Anna emotionally. Jake valued sharing emotionally with Anna, and was able to talk through the continuing difficulties he experienced interacting with his ex-wife, with whom he has two children:

That's one of the things me and her are good at. We discuss everything and anything.... Past relationships aren't a topic that we can't discuss...which is good for me. I talk to her about every time my ex comes over.

This support has been critical for Jake, who feels his drinking is triggered by emotional stress.

I: $\quad$ What are you biggest triggers for alcohol or drugs?

R: When I get off of work I feel entitlement to drink because I just worked for the day, you know. I'm not a very angry person but I know anger will drive me to drink very quickly. When I get upset, emotions, past relationships are a good trigger for me. Top five probably deal with my ex-wife, the relationship 
I'm in, how I'm dealing with my family has a lot to do with relationships, my communication with people. But it's almost like my emotions and keeping that in check.

To counteract this urge to drink at night, Jake made a practice of calling Anna right after work. However, Anna faced her own struggle with addiction. When Jake first started the relationship, he viewed their shared experience with addiction and incarceration as a plus: she understood what he was going through and recognized the signs and triggers that might presage a relapse. However, several months into the relationship when Anna suffered a relapse of her own, the relationship became more threatening to Jake's sobriety than emotionally supportive, and he ended it.

Though relationships quickly and intensively invested in provided an important emotional release valve for men, their short-term nature necessarily limited the impact they could have on desistance goals. Jake's story also suggests that, though "disposable ties" fill important needs, emotional, and otherwise, they also are viewed as less consequential than more committed, long-term relationships, such as Jake's tie to his ex-wife.

Although women faced similar emotional challenges, they rarely described emotional support as a benefit of their romantic relationships with men. While not absent from women's relationships, expressive support did not play the key role it did among our male participants. Women more frequently mentioned turning instead to female family members and friends for such support.

Negative-Relationship Stress. Just as relationships can provide support, they can also bring new sources of stress, such as patterns of conflict and disagreement between partners. Although strain theory suggests that the strain resulting from social relationships can lead to crime (Agnew 1992), there remains very little research detailing the connection between relationship stress and crime.

While relationships could be sources of emotional support, our participants illustrate how the stress created by conflict within relationships can also trigger drug and alcohol use. Because staying sober was one of the greatest challenges of reentry for many of our participants, avoiding stressful relationships was one way to protect against potential relapse. This path toward recidivism seemed more salient, and was more frequently discussed, among our female participants. For our female participants, drugs and alcohol could be used to escape stressful, frustrating, or discouraging situations, of which romantic partnerships were a frequent source. While one-time drug use is not recidivism, a sustained relapse poses a substantial threat to desistance. Lenora, African-American and 52, noted that relationships could be risky because "they get on your nerves, some guys." Implicit in this reasoning is the idea that being in a relationship requires emotional work, and focusing on men might mean women have fewer emotional resources to expend on their own recovery and reintegration. Stressful, conflict-laden relationships are the negative analogue to the emotionally supportive relationships we discussed above, and illustrate how the effects of relationships differ based on the characteristics of the relationship.

When Michelle left prison, she and Luke had been together on and off for 3 years, during which time they both cycled through multiple periods of sobriety 
and relapse. As she explained, they hardly knew each other sober. Nonetheless, as she left prison, she had high hopes for the relationship, describing how they "always came back together." Yet 2 months following her prison release, the couple had broken up, and at 6 months post-release they had reunited, gotten engaged again, begun planning the wedding, and once more broken up. Michelle explained that she had broken up with Luke because he returned to drinking, and the stress of the relationship endangered her own sobriety. She realized that conflict in the relationship could easily trigger a relapse that might result in her reincarceration. She recounted how breaking up with Luke had changed her life:
R:
It's a lot of stress out of my life, and I don't think it would have worked. I think we were holding on to something that we just don't have anymore. It worked out good, but that's a big adjustment because he was a main source of me getting around. Now I'm taking the bus a lot more.
I: $\quad$ How did you know [it wasn't going to work]?
R: Little arguments since I've been out over the stupidest stuff. And I don't need that stress in my life because it had me thinking, "You know what? I just need to go and relax, go have a drink or something." I can't have myself get to that point because then I'll be in prison. So it worked out for the best.

Despite the material support Michelle gained through this relationship, stressful dynamics threatening to her sobriety came to outweigh the benefits, and the two broke up, at least for a time.

Men also described relationship stress as a pathway to relapse. Recall that Jake described his current relationship as the primary emotional support system he had for maintaining sobriety, but also explained that the continuing stress of interactions with former partners could trigger a relapse. Other men echoed Jake's concern with stressors from prior relationships and their connection to drug and alcohol abuse. For example, DeAngelo traced the roots of his alcoholism, a significant contributor to the crimes that led to his incarceration, to a particularly painful ending to his marriage:

\footnotetext{
I was devastated. Like how could you accept these vows knowing that you was this kinda person, knowing that you can't live up to what these vows are saying? I think that's when I really start drinking. I've always drank, but I think that's when I really started drinking. But like I was just hurt. Man, I felt just like mistreated, like I just felt like something that you just don't even care about, something you throw out. I couldn't feel so low.
}

DeAngelo explicitly links the onset of his heavy drinking with the disintegration of this relationship. Over the next few years his drinking accelerated and he was arrested three times for driving while intoxicated.

\section{DISCUSSION AND CONCLUSION}

Criminologists have long recognized that male offenders who enter strong marital relationships with conventional wives are more likely to desist from crime. While past research has largely emphasized the positive implications of high-quality marital relationships between criminal men and noncriminal women, such relationships are now relatively rare among the offender population, and increasing 
numbers of women are involved in the criminal justice system as well. Our aim has been to identify and describe the processes and pathways through which romantic relationships, of all kinds, either facilitated or hampered our participants' efforts to desist from crime.

Our typology delineates six such pathways, grouped within three conceptual categories: material circumstances (instrumental support, role strain), social bonds and patterns of interaction (monitoring and supervision, coercion and negative social control), and emotional supports and stressors (expressive support, relationship stress). This typology identifies both pathways relatively neglected by prior research, as well as aspects of relationships that negatively, as well as positively, influence desistance. ${ }^{7}$ Our findings also identify gender differences in how relationships shape the criminal behaviors of men and women.

First, participants gained material support from relationships, which in many cases helped them avoid homelessness and may have reduced the need for incomegenerating crime. However, particularly for men, we suggested that the desire to be a provider coupled with a failure to secure a legitimate job could lead to continued offending through role strain, as men turned to income-generating crime to meet their own gendered expectations. Second, echoing the dominant literature on marriage and crime, we found that some relationships appeared to provide social control in the form of monitoring and supervision, as participants altered their behaviors to align with partners' expectations and norms. However, we also found that some partnerships, rather than providing a conventionalizing influence, may have been a source of criminal opportunity, such as partners providing access to drugs, or negative social control as in the case of Jada, coerced by her partner to engage in illegal activity. Third, male participants received emotional support from their partners, which helped them to deal with stress, maintain their sobriety, and thereby adhere to their desistance goals. However, in other cases, the conflict and emotional stress that occurred within relationships may have triggered relapse and thereby led to continued offending.

Our findings have mixed implications for social control theory, the dominant perspective in the literature on marriage and desistance. Although our results support the idea that romantic relationships (particularly marriage) characterized by strong bonds to conventional partners inhibit offending, it is important to note that upon release from prison, only one of our participants could claim to be strongly bonded to a conventional partner. We thus depart from prior literature by expanding research inquiry to encompass the diversity of relationships within which exoffenders are increasingly involved. Although we do find evidence for some of the processes identified by theories of social control, we also uncover instances in which relationship engagement promoted criminal offending, suggesting that it is important to attend not just to the presence and quality of the social bond, but to interactional aspects of the relationship as well, such as the dynamics of bonds formed with unconventional partners, and the implications of partnership for identity.

\footnotetext{
7 Although it is possible to conceptually isolate the positive and negative aspects of relationships, it is important to recognize that for particular subjects and relationships, they were intertwined.
} 
It is also important to recognize that former prisoners, and particularly women, often seem to become romantically involved with partners similar to themselves in terms of addiction and criminal history, which is likely to affect these relationships' potential to facilitate desistance (Rhule-Louie and McMahon 2007; Simons et al. 2002). While such partnerships need not spark a return to crime or substance abuse, particularly if the partner is committed to desistance and sobriety themselves, such pairings nonetheless appear to heighten the risk of relapse. As Jane explained after relapsing 13 months following her prison release, "My husband, it's kind of like [pauses] we hold each other up or we pull each other down together. And we're in that pull-down phase."

Our results also highlight the importance of "disposable ties" among the urban poor, those quickly initiated, deeply invested in, and easily abandoned (Desmond 2012). Many of our research participants faced significant hurdles and substantial stress following release from prison. Dependent as they were upon partners for transportation, housing, child care, and spending money, and for men, emotional support, our participants quickly became tightly tied to partnerships newly formed. Yet barraged by the stresses of poverty, addiction and relapse, incarceration, or merely community adjustment, these relationships often ended as quickly as they had begun. Though many relationships were fractious and prone to breakup, akin to those documented by Desmond, it is important to note that relationships also evidenced a certain fluidity, in that many would be rekindled, or drawn upon for support, later down the line. Thus subjects' relationships did not seem quite as "disposable" as those described by Desmond. For some, having children together seemed linked with relationship reunion, while for others emotional or physical explanations seemed more salient. For most, material need provided an important impetus. While the fluid nature of these ties challenges a causal interpretation of their role, it is possible to suggest pathways through which these relationships influenced offenders' desistance or recidivism processes.

This research also advances the desistance literature's treatment of gender by examining how gender conditions the desistance implications of romantic partnership, and by challenging conceptions of gender implicit in much criminological theorizing that focuses on offending men partnered with conventional women (Messerschmidt 1993; Sampson and Laub 1993).We find both similarities and differences in the ways in which romantic relationships influence men and women's desistance processes. Processes that functioned similarly for men and women included material support and the emotional stress of relationship conflict. However, important gender differences did emerge as well. These differences reflected practices linked with traditional gender roles, as well as the reality of men's greater involvement in criminal and antisocial behaviors (Sampson and Laub 1993; Sampson et al. 2006). Men were more likely to report experiencing role strain as a result of their inability to contribute financially to their partnership, though they also experienced more emotional support. In contrast, women were less subject to monitoring and supervision from their partners, often because their partners were criminally engaged or substance abusing. For the same reasons, relationships were more likely to present new criminal opportunities for women who were returning from prison. 
The reader should recognize certain limitations of this research. As a qualitative study with a relatively small sample, it is impossible to provide information on the prevalence or frequency of the pathways or processes that we identify. Although we have emphasized only those that appear consistently across multiple participants and multiple relationships, it is possible that additional pathways would be uncovered in a larger, more representative sample or that some of the pathways we describe are relatively rare.

In addition, our small sample means that we cannot examine additional sources of potentially important variation in addition to gender, as further dividing the sample would result in subgroups that were simply too small for meaningful analysis. For example, we have not examined differences by race. While it was possible to determine that our black participants faced greater material hardship due to lack of family resources and more disadvantaged neighborhoods, we were unable to determine whether (or how) relationships might matter differently for black and white offenders. Because the larger social science literature on romantic relationships finds significant variation by race, as well as age and the presence of children, future work on relationships and desistance should investigate these potential sources of heterogeneity.

Despite these limitations, this work provides an important first step in redirecting the conversation about romantic relationships and crime to encompass the spectrum of relationships within which contemporary offenders are involved. Though fluid and fractious or even fleeting relationships with partners tenuously conventional (or not at all) may play a less strictly positive role in desistance processes, for those leaving prison with few social or material resources to turn to, such partnerships may nonetheless prove crucial for criminal trajectories.

\section{REFERENCES}

Agnew, Robert. 1992. "Foundation for a General Strain Theory of Crime and Delinquency." Criminology 30: 3: 47-86.

Alarid, Leanne F., Velmer S. Burton, and Francis T. Cullen. 2000. "Gender and Crime Among Felony Offenders: Assessing the Generality of Social Control and Differential Association Theories." Journal of Research in Crime and Delinquency 37: 2: 171-199.

Barnes, J.C., and Kevin M. Beaver. 2012. "Marriage and Desistance from Crime: A Consideration of Gene-Environment Correlation.” Journal of Marriage and Family 74: 1: 19-33.

Bersani, Bianca, John Laub, and Paul Nieuwbeerta. 2009. "Marriage and Desistance from Crime in the Netherlands: Do Gender and Socio-Historical Context Matter?" Journal of Quantitative Criminology 25: 1: 3-24.

Bumpass, Larry, and Lu Hsien-Hen. 2000. “Trends in Cohabitation and Implications for Children's Family Contexts in the United States." Population Studies 54: 1: 29-41.

Capaldi, Deborah, Hyoun Kim, and Lee Owen. 2008. "Romantic Partners' Influence on Men's Likelihood of Arrest in Early Adulthood." Criminology 46: 2: 267-299.

Chesney-Lind, Meda and Randall G. Shelden. 1998. Girls, Delinquency, and Juvenile Justice. New York: Wiley.

Cobbina, Jennifer E., Beth M. Huebner, and Mark T. Berg. 2010. "Men, Women, and Postrelease Offending: An Examination of the Nature of the Link Between Relational Ties and Recidivism." Crime \& Delinquency 58: 3: 331-361.

Cohen, Lawrence C. and Marcus Felson. 1979. "Social Change and Crime Rate Trends: A Routine Activity Approach.” American Sociological Review 44: 4: 588-608.

Cohen, Sheldon. 2004. "Social Relationships and Health.” American Pyschologist 59: 8: 676-684. 
Colvin, Mark, Francis T. Cullen, and Thomas Vander Ven. 2002. "Coercion, Social Support, and Crime: An Emerging Theoretical Consensus.” Criminology 40: 1: 19-42.

Cullen, Francis T. 2004. "Social Support as an Organizing Concept for Criminology: Presidential Address to the Academy of Criminal Justice Sciences.” Justice Quarterly 11: 4: 527-738.

Daly, Kathleen. 1994. Gender, Crime, and Punishment. New Haven, CT: Yale University Press.

Desmond, Mathew. 2012. "Disposable Ties and the Urban Poor." American Journal of Sociology 117: 5: 1295-1335.

Duncan, Greg, Bessie Wilkerson, and Paula England. 2006. "Cleaning Up Their Act: The Effects of Marriage and Cohabitation on Licit and Illicit Drug Use.” Demography 43: 4: 691-710.

Edin, Kathryn and Maria Kefalas. 2005. Promises I Can Keep. Berkeley: University of California Press.

Ganem, Natasha M., and Robert Agnew. 2007. "Parenthood and Adult Criminal Offending: The Importance of Relationship Quality." Journal of Criminal Justice 35: 6: 630-643.

Gerstel, Naomi. 2011. "Rethinking Families and Community: The Color, Class, and Centrality of Extended Kin Ties." Sociological Forum 26: 1: 1-20.

Giordano, Peggy, Stephen Cernkovich, and Jennifer Rudolph. 2002. "Gender, Crime, and Desistance: Toward a Theory of Cognitive Transformation.” American Journal of Sociology 107: 4: 990-1064.

Glueck, Sheldon and Eleanor Glueck. 1950. Unraveling Juvenile Delinquency. New York: Commonwealth Fund.

Glueck, Sheldon and Eleanor Glueck. 1968. Delinquents and Non-Delinquents in Perspective. Cambridge, MA: Harvard University Press.

Greenfeld, Lawrence A. and Tracy L. Snell. 1999. Women Offenders. Washington, DC: Bureau of Justice Statistics.

Griffin, Marie L. and Gaylene S. Armstrong. 2003. "The Effect of Local Life Circumstances on Female Probationers' Offending." Justice Quarterly 20: 2: 213-239.

Harm, Nancy, and Susan D. Phillips. 2001. "You Can't Go Home Again: Women and Criminal Recidivism." Journal of Offender Rehabilitation 32: 3: 3-22.

Haynie, Dana, Peggy Giordano, Wendy Manning, and Monica Longmore. 2005. "Adolescent Romantic Relationships and Delinquency Involvement." Criminology 43: 1: 177-210.

Hirschi, Travis. 1969. Causes of Delinquency. Berkeley: University of California Press.

Horney, Julie D., Wayne Osgood, and Ineke H. Marshall. 1995. "Criminal Careers in the Short-Term: Intra-Individual Variability in Crime and Its Relation to Local Life Circumstances." American Sociological Review 60: 5: 655-673.

King, Ryan, Michael Massoglia, and Ross MacMillan. 2007. "The Context of Marriage and Crime: Gender, the Propensity to Marry, and Offending in Early Adulthood." Criminology 45: 1: 33-65.

Kuzel, Anton J. 1992. "Sampling in Qualitative Inquiry." In B.F. Crabtree and Miller, W.L. (eds.), Doing Qualitative Research: pp. 31-44. London: Sage.

Laub, John H. and Robert J. Sampson. 1993. "Turning Points in the Life Course: Why Change Matters to the Study of Crime." Criminology 31: 3: 301-325.

Laub, John H., and Robert J. Sampson. 2003. Shared Beginnings, Divergent Lives: Delinquent Boys to Age 70. Cambridge, MA: Harvard University Press.

Leverentz, Andrea. 2006. "The Love of a Good Man? Romantic Relationships as a Source of Support or Hindrance for Female Ex-Offenders." Journal of Research in Crime and Delinquency 43: 4: 459-488.

Lin, Nan. 1986. "Conceptualizing Social Support.” In N. Lin, Dean, A. and Edsel, W. (eds.), Social Support, Life Events, and Depression: pp. 17-30. Orlando, FL: Academic Press.

Lofland, John and Lyn H. Lofland. 1995. Analyzing Social Settings: A Guide to Qualitative Observation and Analysis. Belmont, CA: Wadsworth.

Messerschmidt, James W. 1993. Masculinities and Crime: Critique and Reconceptualization of Theory. Lanham, MD: Rowman \& Littlefield.

O'Brien, Patricia. 2001. Making It in the "Free World": Women in Transition from Prison. Albany: State University of New York Press.

Osgood, D.Wayne, Janet K. Wilson, Patrick M. O’Malley, Jerald G. Bachman and Lloyd Johnston. 1996. "Routine Activities and Individual Deviant Behavior." American Sociological Review 61: 4: 635655.

Rhule-Louie, Dana and Robert J. McMahon. 2007. "Problem Behavior and Romantic Relationships: Assortative Mating, Behavior Contagion, and Desistance." Clinical Child and Family Psychology Review 10: 1: 53-100.

Sampson, Robert and John Laub. 1993. Crime in the Making: Pathways and Turning Points Through Life. Cambridge, MA: Harvard University Press.

Sampson, Robert, John Laub, and Christopher Wimer. 2006. "Does Marriage Reduce Crime? A Counterfactual Approach to Within-Individual Causal Effects.” Criminology 44: 3: 465-508. 
Siennick, Sonja E. 2011. "Tough Love? Crime and Parental Assistance in Young Adulthood." Criminology 49: 1: 163-195.

Simons, Ronald L., Eric Stewart, Leslie Gordon, Rand Conger Jr, and Glen Elder. 2002. "Test of LifeCourse Explanations for Stability and Change in Antisocial Behavior from Adolescence to Young Adulthood." Criminology 40: 2: 401-434.

Smock, Pamela. 2000. "Cohabitation in the United States: An Appraisal of Research Themes, Findings, and Implications." Annual Review of Sociology 26: 1-20.

Smock, Pamela, Wendy Manning, and Meredith Porter. 2005. "Everything's There Except Money: How Economic Factors Shape the Decision to Marry Among Cohabiting Couples." Journal of Marriage and Family 67: 3: 680-696.

Steffensmeier, Darrell, and Emilie Allan. 1996. "Gender and Crime: Toward a Gendered Theory of Female Offending." Annual Review of Sociology 22: 459-487.

Sterk, Claire E. 1999. Fast Lives: Women who Use Crack Cocaine. Philadelphia, PA: Temple University Press.

Thompson, Melissa and Milena Petrovic. 2009. "Gendered Transitions." Journal of Research in Crime and Delinquency 46: 3: 377-408.

Umberson, Debra, Robert Crosnoe, and Corinne Reczek. 2010. "Social Relationships and Health Behavior Across the Life Course." Annual Review of Sociology 36: 139-157.

Warr, Mark. 1998. "Life-Course Transitions and Desistance from Crime.” Criminology 36: 2: 183-216.

Western, Bruce. 2007. Punishment and Inequality in America. New York: Russell Sage Foundation.

\section{Supporting Information}

Additional Supporting Information may be found in the online version of this article:

$$
\text { Appendix. Sampling and Interview Methodology }
$$

